\title{
THE APPLICATION OF CLASSROOM MANAGEMENT IN ENGLISH LANGUAGE TEACHING TO INCREASE STUDENTS' SPEAKING ABILITY AT TENTH GRADE OF SMK TRISAKTI BANDAR LAMPUNG
}

\author{
Anita Susanti \\ STKIP Kumala Lampung, Metro \\ Email: nietha1987@yahooo.id
}

\begin{abstract}
This research focused on the application of classroom management in English language teaching to increase students' speaking ability at private vocational high school at Bandar Lampung. Data come from tenth class $\mathrm{X}$ accounting 1consists of 35 students involving a writer and an English teacher. The research was conducted through a Classroom Action Research (CAR). The result showed that classroom management could be used to increase students' speaking in learning English by implementing proper classroom management. Classroom management could be effective if it is supported by the ability of the teacher in managing a classroom. How teachers' talk and behave were important factors in managing a class. Making a classroom climate was comfortable and conducive by proper classroom managing and adequate classroom facilities. The successful application of classroom management can be seen from the students' positive response and their active participation in speaking learning activities.
\end{abstract}

Keyword : Speaking, Classroom Management, English.

\section{INTRODUCTION}

This research focused on the application of classroom management in English language teaching to increase students' speaking at the tenth class of SMK Trisakti Bandar Lampung. Background of this research is problem of classroom management implementation in a school influence students' motivation to increase speaking English. Learning English is a study of the language components and language skills. English components are grammar, vocabularies, pronunciation, and spelling. Language skills are Listening, Reading, Speaking, and
Writing. Speaking is one of the most difficult skills to be mastered by students.

Learning to speak foreign languages is the one of difficult aspect in language learning. Teacher has an important role to help students in developing speaking skill of language learning and motivate them to speak. Helping students to increase their speaking skill is not only as the way to make them pass the examination but it's for their need to face the world. Speaking activities relate to listening and pronunciation understanding. Where both of them have a role in speaking which a speaker produces utterances 
(Encoding Process) and a listener listens these utterances in his brain (Decoding Process)(Karwati, Euis \& Priansa, Donni;, 2014).

Students are expected to use their speaking or do English conversation to express their mind and their feeling in community wherever they are. They also can tell their experiences and others. The fact shows that speaking is not easy. Some reasons from that fact are first; to produce utterances, they need spontaneity, good pronunciation, good grammar and having clear mind. Second; to produce utterances, students are asked to interact directly with other people. In a class, there is an interaction between students and teacher. This interaction process relates to teaching and learning activity. It needs teachers' ability and school facilities to make students' comfortable in learning. The important factor is classroom management. It has crucial influence for the success of teaching and learning process.

Teachers' physically has important role in classroom management. Teachers' dress, teachers' body language, teachers' eye contact, and teachers' movement can influence classroom situation become more joyful. Most of teachers always stay at their chair and they seldom do any movement that can make students bored and asleep. This situation can influence teaching and learning activity. The way of teaching is a teacher must be creative so that it can increase motivation and students' confidence in learning process. The crucial instrument of teachers is voice. How teachers' speaking and teachers' voice is very important and having strong influence in the classroom. A teacher has to speak loudly and clearly because most of students make a noise in the classroom. Those things can make teaching and learning process effectively and students can understand the material. In classroom, students usually sit in line chairs arrangement and a table in front of two chairs. While a group discussion is held, seating arrangement will be disorder. Other problems when teachers teach in class are noisy class and crowded class. Sometimes, students are always busy with their business and they do not attend to teachers' explanation and teachers' instructions. When they are given a task such speaking task, they are always passive and silent. Only some of them are enthusiasm to speak up.

A teacher has to be smart to solve these problems by doing proper seating arrangement and doing proper classroom management. It is important for teachers to make classroom planning and classroom organizing. Both things are parts of classroom management. Classroom management consists of two words; management is relation way to reach the goal by using other people; class is a goup of people that doing learning activities.(Karwati, Euis \& Priansa, Donni;, 2014)

Management is very important to be implemented in classroom activities. Need of management in class is not only effectiveness need and efficiency of learning process through optimal classroom function. However more than that, management in class is response for the biggest development 
of education quality. Teachers must be capable to produce the best students based on education function in National Education System that is "mengembangkan kemampuan dalam membentuk watak serta peradaban bangsa yang bermartabat dalam rangka mencerdaskan kehidupan bangsa, bertujuan untuk berkembangnya potensi peserta didik agar menjadi manusia yang beriman dan bertakwa kepada Tuhan Yang Maha Esa, berakhlak mulia, sehat, berilmu,cakap, kreatif, mandiri, dan menjadi warga negara yang demokratis serta bertanggung jawab". A creative teacher is able to implement the functions of management in every programme and activities in the class.

Based on the interview with the teacher, it has known that from 35 students only some students who could use English in speaking, the others tend to be passive and silent. And it has known that teachers seldom use good managing in class and the others use the conventional system management. The application of various ways in classroom management aims to create a comfortable and fun situation in learning and give encouraging result.

The research was conducted through a Class Action Research (CAR) because CAR was done to diagnosing and solving problem. CAR is the accuracy of the learning process in action form that is deliberatly emerged and happened altogether in a class. (Arikunto, 2006).

The purpose of this research is to determine the result of students' learning during the instructional process by managing a class with some activities. The successful leaning can be determined based on the presentation, observation and student activities in the class. The research was done at SMK Trisakti Bandar Lampung tenth class. It is located at Khairil Anwar Street 10 Durian Payung Bandar Lampung. Students' speaking skill at tenth class is low because teacher still uses conventional managing in teaching and learning process.

\section{THEORITICAL REVIEW Speaking Skill}

Speaking is a skill to pronounce the articulation sound or word to express, tell or send a thought, idea and feeling. Speaking is a tool to communicate ideas that arranged and developed appropriate with the need of audience and listener. (Tarigan, 2008). It can be concluded that speaking is an oral communication tool and a speaking skill through of vocabularies development need to make effective speaking activity.

There are three main reasons for getting students to speak in the classroom: (Harmer, 2007)

a. Speaking activities provide reheasel opportunities changes to practice real life speaking in the safety of the classroom

b. Speaking task in which students try to use any or all of language they know provide feedback for both teachers and students.

c. In speaking, students have opportunities to activate the various elements of language they have stored in their brains, the more automatic their use of these elements become.As a result, students gradually become autonomous language users. This 
means that they will be able to use words and phrases fluency without very much concious thought. (Harmer, 2007)

\section{Communication activities}

Communication is a process where two people or more build or share informations to other (Sugiyo, 2005). Communication activities are activities in which the students are put into situation which require them to use English freely to achieve a particular purpose (non linguistic purpose). These activities are openended, unpredictable, and not limited to certain linguistic items. (Djuwarsih, 2008)

It means that communication activities are the process to communicate in the situation where people must speak or share informations in an activity. In learning english, communication activity is usually done in english speaking activity. The students are asked to speak and teachers should make a situation where they should use english in speaking activity.

The aims of communication activities (Djuwarsih, 2008):

1. To gain sufficient confidence to use english in expressing thought/ideas/opinions and to project themselnes as interesting individuals

2. To improve their fluency in english speaking i.e. learning to speak spontaneously and confident without pauses and hesitation

3. Learning how to start off, continue, and take a part in discussion, conversation, etc.

4. To learn how to speak continously
5. To learn more english through having to try and say many things in order to achieve their purpose and trough with their peers

6. Learning to think in english

7. To improve the ability and to communicate efeectively in English Teachers' role in communication activities (Djuwarsih, 2008)

a. As guide and conductor: giving students clear and simple instructions about what they are going to do

b. As a motivator: motivating and encouraging students so that they want to communicate to each other to achieve the particular purpose of the activity.

c. As an organizer: organizing the lesson, classroom, and the students in the most suitable way and in relax situation or atmosphere for the particular activity.

d. As a controller: checking whether the students have understood and remembered what they are supposed to do, nothing necessary errors and problems to deal with in the future lessons.

e. As a facilitator: joining and getting involved in a group (being member) during the discussion activity, giving helps when the group cannot continue in communication, do not force them to use English but encourage them to use it by using it in group even 
though students use Indonesian language.

However, teachers often find some problems when they teach speaking and use communication activities. The problems are noisy class and crowded class. The teacher can minimize these problems by making the comfortable situation by arranging classroom management. Classroom management relates to teaching speaking and makes the class activities will be condusive and effective.

\section{Scoring of speaking skill}

For scoring of speaking skill, the table on oral presentation criteria is going to be used to evaluate students' performance. Each criterion is designed to ease teacher to score students' presentation. The criteria used to evaluate students' performance are based on Brown (2007), He suggets there are at least six criteria to assess speaking skill: pronunciation, fluency, grammar, vocabulary, discourse, feature, and task accomplishment (Brown, 2007). In addition, presentation skill checklist will be added to oral presentation assessment criteria.

Table 1. Oral Presentation Assessment Criteria (Brown, $\mathrm{H}$ D \& Abeywickrama, P, 2010)

\begin{tabular}{|l|c|c|c|c|c|c|}
\hline \multicolumn{1}{|c|}{ Criteria } & $\mathrm{E}$ & $\mathrm{V}$ & $\mathrm{G}$ & $\mathrm{S}$ & $\mathrm{P}$ & $\begin{array}{c}\text { Comme } \\
\mathrm{nt}\end{array}$ \\
\hline SPEAKING & & & & & & \\
SKILL and & & & & & & \\
Fluency & & & & & \\
Coherence \\
Speak fluently \\
with only rare \\
repetation or \\
self-correction \\
Speaks \\
coherently and \\
developstopics \\
fully and \\
appropriately
\end{tabular}

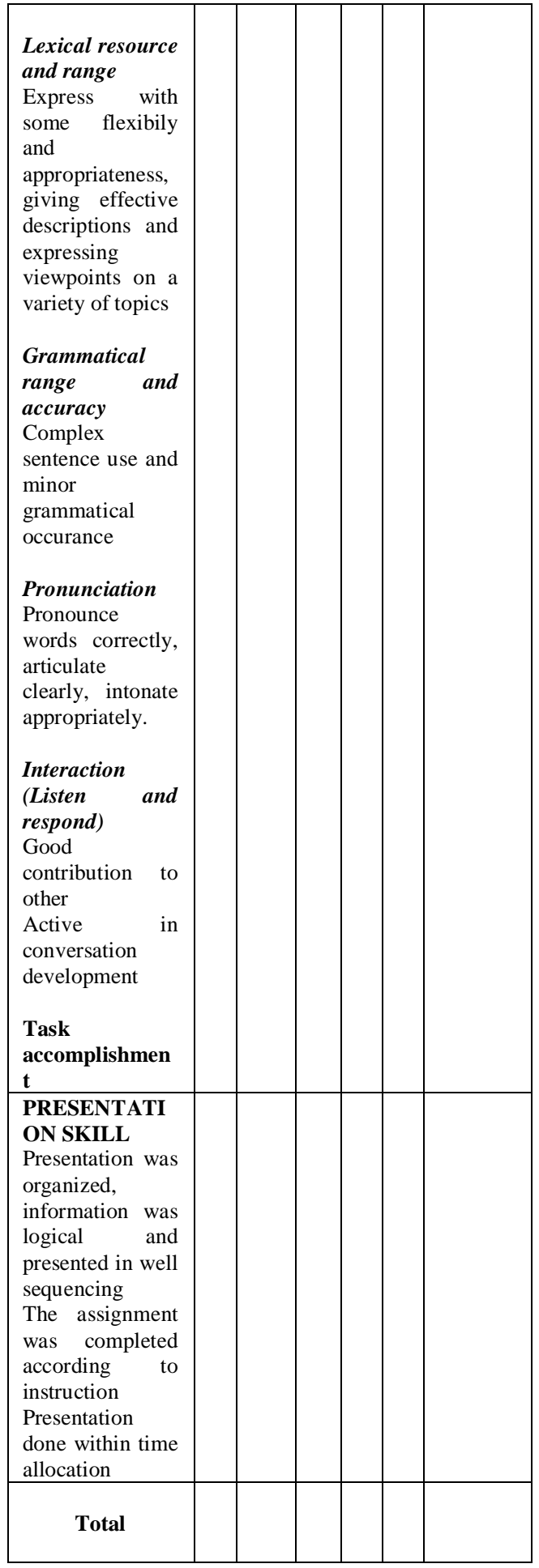

Comment: 
Table 2. Rating Points

\begin{tabular}{ccc}
\hline Initial & Criteria & Score \\
\hline E & Excellent & 5 points \\
VG & Very good & 4 points \\
G & Good & 3 points \\
S & Satisfactorily & 2 points \\
P & Poor & 1 points \\
\hline
\end{tabular}

\section{Classroom management}

Classroom Management is a teacher skill to create condusive climate learning and controll an error in learning activities (Mulyasa, 2006). Classroom management based on Karwati and Priansa is the effort to planning, organizing, actualizing, and observing the program and activity in the class in order to make learning and teaching process systematic, effective, and efficient so all students' potential can be optimal (Karwati, Euis \& Priansa, Donni;, 2014).

It can be said management is crucial to be implemented in activities in the classroom. The necessity for management in the class is not only about effectiviness and efficiency of learning process trough optimizing classroom function but it is a response from demand of education quality development that is begun from classroom.

There are some kinds of classroom that can be observed by teacher:

1. Noisy classroom: Teachers always waste their time to control noisy classroom. That noise is caused by students' attitude; they are difficult to be given instructions.

2. Conducive classroom: This class has positive atmosphere for learning and teaching activities. Teacher can create exciting situation and condition for students. The learning method can be applied and teacher will be more attractive and can influence students' creativity.

3. Quite and discipline classroom: a creative teacher can create the quite and discipline classroom. Students obey the regulation from teacher.

4. Natural classroom:

If we want to manage classrooms effectively, we have to able to handle range variables. These include how the classroom space is organised, whether the students are working on their own or in a groups and how we organise classroom time. (Harmer, 2007)

Classroom management is about the function of all things in the classroom so it can give contribution to reach learning effectiveness. To conduct it, classroom management has some activities which must be done. Classroom management activities consist of: 1). Management of students, 2). Management of facilities. (Karwati, Euis \& Priansa, Donni;, 2014). Classroom management activities are explained in this diagram:

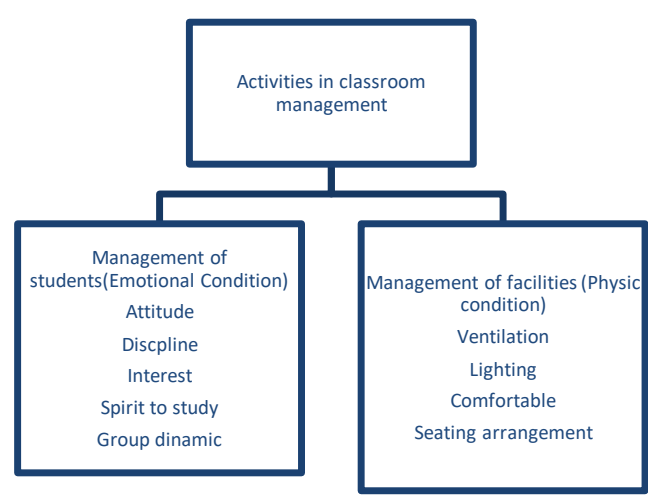


The goal of Classroom Management is to create effectiveness and efficiency to achieve learning purpose. The activities of physic management and socio-emotional management are part of goal achievement in learning and study of students. (Karwati, Euis \& Priansa, Donni;, 2014) The success of classroom management in reaching the goal of learning is influenced some factors, mainly: (Djamarah, S B \& Zain, Azwan;, 2006)

1. Physic environment consist of: classroom for learning process, seating arrangement, ventilation and light management, and goods storage.

2. Socio-Emotional conditions consist of: leader type (teacher), teachers' attitude, teachers' voice, and good relationship.

3. Organizational Condition consists of: students' internal factors and students' external factors.

\section{Application of classroom management}

There are some ways to manage a classroom. A teacher must be creative to apply some creation in managing a class. English teacher should manage a class by giving some instructions to the students as follows: (Gower, Roger \& Walters, Steve, 1983)

1. Make a comfortable class by using some wall décor and class cleanness.

2. Setting up controlled practice activity; generally speaking, what students should be doing controlled practice activities, such as a drill, is so obvious that instruction are unnecessary.
However, it may occasionally be necessary to demonstrate a new kind of drill, even a teacher-tostudents drill, before using it, so:

- Get everybody's attention, give the prompt then move to make it clear you are in the role pf the students and give the response

- Try out the drill with one of the better students so that the rest of the class can see. If the better student cannot do it, you will have to simplify your explanation or break it up and do the drill stage by stage, explaining each bit as you go along or

- Write an example of the drill on the board and do the practice from that.

3. Directing controlled practice

Your instruction will need to be as simple as possible. Classroom instructions however are usually best learned directly as language for an exercise. Here are some common ones: tell me, repeat, everybody, again, try again, look at the board, read, say, etc.

4. Organizing seating arrangement and determine who sits next to whom

You might give each student a number or some kind of symbol. In which cas, it might be the number fives who listen for what they should do:

$\mathrm{T}$ : Right, listen to your number. One, two, three.Four, five. Juan, what's your number?

$\mathrm{J}$ : three

$\mathrm{T}$ : Abdullah?

A : Four

$\mathrm{T}$ : Right. Listen. All of fours are going to..... all the threes ..... 
5. Setting written and speaking work by pair or individual work; it's very easy, having practiced for example a dialogue, to give a rather casual instruction such as Right. I want you to write a couple similar dialogues substituting your own ideas where you can and then wonder why the students are not able to do what you want.

6. Further hints

- Support instructions with pictures, physical guidance and gestures wherever possible

- Be consistent, especially with lower-level classes: use the same set of words for the same instruction

- Develop a signal, like the word Right or Listen which students will learn to recognize as the cue for an instruction

- Make sure the students know when to begin an activity (e.g say something like Everyone. NOW).

\section{FINDING AND DISCUSSION}

Observation was conducted to learn the condition of tenth students at Trisakti Vocational High School during the process teaching and learning before implementing effective classroom management. Based on the observation result showed that the class is passive, it is only two or three students concern in speaking. Most of students did not participate in learning activities such as conversation and presentation. They are shy to speak and give oral conversation. The classroom management is not effective. Teacher did not use effective seating arrangement and she did not give clear instruction to students. Those are a problem and finding a solution should be done to improve the quality of students' speaking.

In the pre test result showed that mean score was $53,5 \%$.It consist of 6 students $(17,1 \%)$ are active participant. Those are the students who pass KKM from 35 students in the class. On other hand, the number of passive participant showed 29 students $(82,9 \%)$. In speaking test, it can be seen that none of students get score "Excelent", 2 student gets score "Very Good", 4 student ges score "Good", 7 students get score "Fair" and 13 students gets score "Satisfactory" and 9 student get score "Poor". In other words, using convensional classroom management was said fail because there are 22 students could not reach KKM. The pre test had done before Classroom Action Research in a presentation form. Then the score was taken in six criteria as stated by Brown. Based on the result, it is indicated that the students' speaking skill was very low.

There was a significant score improvement in the post test result. Based on the data analysis there were 15 students $(42,9 \%)$ passed KKM from 35 students. The average score was 76,25. In the test, none of students get score "Excellent", 4 students get score "Very Good", 6 students get score "Good", 10 students get score"Fair", 9 students get score satisfactory, and 6 students get score"Poor"It means there is a significant improvement when teacher use the effective classroom management to increase students' speaking skill. 
According to the data above, it can be concluded that the goal of this research has been achieved successfully. In other words, the application of classroom management in English language teaching can increase students' speaking ability.

\section{CONCLUSION}

Using proper classroom management can increase students in speaking English for the students of SMK Trisakti Bandar Lampung class $\mathrm{X}$ accounting 1. It can be proven through observation, interview, Pre test \& Post test. The average score and students total score improvement were improve in the post test after teacher implemented the proper management in the class. The students was excited and enthusiasm in following the learning activities when the classroom became more comfortable and more condusive. The application of classroom management is successful because the average increases high. The proper management also increases student's activeness in speaking.

\section{REFERENCES}

Arikunto, S. (2006). Prosedur Penelitian Suatu Pendekatan Praktik. Jakarta: Rineka Cipta.

Brown, H D \& Abeywickrama, P. (2010). Language Assessment: Principles and Classroom Practice (2nd Ed.). New York: Pearson Education, Inc.
Brown, H. D. (2007). Teaching by Principle: An Interactive Approach to Language Pedagogy (3rd Ed.). New York: Pearson Education, Inc.

Djamarah, S B \& Zain, Azwan;. (2006). Guru dan Anak Didik dalam Interaksi Edukatif. Jakarta: Rineka Cipta.

Djuwarsih. (2008). Learning and Teaching Strategy. Bandar Lampung: Wijaya Saputra.

Gower, Roger \& Walters, Steve. (1983). Teaching Practice. Oxford, London: British Library Catalouging.

Harmer, J. (2007). How to teach English. Camridge, UK: Pearson Longman.

Karwati, Euis \& Priansa, Donni;. (2014). Manajemen Kelas. Bandung: Alfabeta.

Mulyasa, E. (2006). Manajemen Berbasis Sekolah. Bandung: PT.Remaja Rosdakarya.

Sugiyo. (2005). Komunikasi Antar Pribadi. Semarang: UNNES Press.

Tarigan, H. G. (2008). Berbicara sebagai suatu Keterampilan Berbahasa. Bandung: Angkasa. 